\title{
Influence of Dietary Protein Levels on $\beta$-Alanine Aminotransferase Expression and Activity in Rats
}

\author{
Satoshi Ito, Tomoko Ohyama, Yasuhide Kontani, Koichi Matsuda, \\ Shigeko Fujimoto SAKATA and Nanaya TAMAKI* \\ Laboratory of Nutritional Chemistry, Faculty of Nutrition and High Technology Research Center, \\ Kobe-Gakuin University, Kobe 651-2180, Japan
}

(Received September 2, 2000)

\begin{abstract}
Summary $\beta$-Alanine-oxoglutarate aminotransferase ( $\beta$-AlaAT I) and $\beta$-alanine-pyruvate aminotransferase ( $\beta$-AlaAT II) catalyze the transamination reaction of $\omega$-amino acids such as $\beta$-alanine, $\beta$-aminoisobutyrate, and $\gamma$-aminobutyrate, amino acids that are not protein constituents. The influence of dietary protein levels on the expression and activities of these enzymes was investigated by using male rats. Both $\beta$-AlaAT I and $\beta$-AlaAT II activities in the liver were increased with the level of protein in the diet in accordance with changes in their mRNA levels. However, the $\beta$-AlaAT I activity in the kidney was increased by proteinfree and low-protein diets in relation to changes in its mRNA level. On the other hand, the level of $\beta$-AlaAT II activity in the kidney was slightly decreased by a protein-free diet. Neither $\beta$-AlaAT I nor $\beta$-AlaAT II activities in the kidney were affected by a high-protein diet. These results suggested that $\beta$-alanine may be used efficiently in animals fed a proteinfree or low-protein diet because the kidney provides $\beta$-alanine by means of the hydrolysis of $\beta$-alanyl-L-histidine (carnosine). The addition of $\beta$-alanine to the diet significantly activated $\beta$-AlaAT I in the kidneys of rats in accordance with changes in its mRNA level. In the rat brain, $\beta$-AlaAT I activity was not altered by the dietary protein level or by the $\beta$-alanine diet, and $\beta$-AlaAT II activity was not detected.
\end{abstract}

Key Words aminobutyrate aminotransferase, $\beta$-alanine-pyruvate aminotransferase, lowprotein diet, high-protein diet

$\beta$-Alanine and $\mathrm{D}-\beta$-aminoisobutyrate are synthesized from uracil and thymine, respectively, by dihydropyrimidine dehydrogenase, dihydropyrimidinase, and $\beta$-ureidopropionase, which are distributed in the cytosolic fraction of animal cells (1-4). Some $\beta$-alanine is converted to $\beta$-alanylhistidine (carnosine) in muscle (5). However, most of it and D- $\beta$-aminoisobutyrate are further catabolized to malonate semialdehyde and methylmalonate semialdehyde, respectively, by transamination in the mitochondrial fraction $(6-8)$.

$\beta$-Alanine is catabolized by $\beta$-alanine-oxoglutarate aminotransferase (aminobutyrate aminotransferase, EC 2.6.1.19; $\beta$-AlaAT I) (6) and $\beta$-alanine-pyruvate aminotransferase (D-3-aminoisobutyrate-pyruvate aminotransferase, EC 2.6.1.40; $\beta$-AlaAT II) (7), and D- $\beta$ aminoisobutyrate is transaminated only by $\beta$-AlaAT II. An analysis of their physicochemical, enzymatic, and immunological characteristics and their amino acid sequence indicated that $\beta$-AlaAT I is identical to $\mathrm{L}-\beta$ aminoisobutyrate aminotransferase (EC 2.6.1.22) (9),

* To whom correspondence should be addressed.

E-mail: tamaki@nutr.kobegakuin.ac.jp

Abbreviations: $\beta$-AlaAT I, $\beta$-Alanine-oxoglutarate aminotransferase (aminobutyrate aminotransferase); $\beta$-AlaAT II, $\beta$ alanine-pyruvate aminotransferase (D-3-aminoisobutyratepyruvate aminotransferase), GABA, 4-aminobutyrate. and $\beta$-AlaAT II is D-3-aminoisobutyrate-pyruvate aminotransferase (EC 2.6.1.40), alanine-glyoxylate aminotransferase 2 (EC 2.6.1.44), aminolevulinate aminotransferase (EC 2.6.1.43), 2-aminobutyrate aminotransferase, and dimethylarginine-pyruvate aminotransferase (10).

The amino acid sequence of the coding region of rat liver $\beta$-AlaAT I $(11,12)$ contains the same 500 residues as those from pig (13) and human (14). Most mitochondrial proteins are synthesized on cytosolic ribosomes and are transported into the mitochondoria to be cleaved to their mature form. The precursor of $\beta$-AlaAT I from rat contains a leader peptide of 27 amino acids. In the rat liver and kidney, however, the mature brain type $\beta$-AlaAT I is further cleaved by a mintochondrial alternative peptidase (11). Therefore the mature $\beta$ AlaAT I consists of 473 and 466 amino acids from the brain and liver, respectively. The size of mature kidney $\beta$-AlaAT I is the same as that from the liver (11). $\beta$ AlaAT II consists of a mature enzyme of 473 amino acid residues and a 39-amino terminal segment, with amino acids attributed to the leader peptide $(12,15)$.

In a previous study (16), we found that the activities of $\beta$-AlaAT I and $\beta$-AlaAT II from rat liver were dependent on the amount of protein in the diet. It is well known that $\beta$-alanine and $\beta$-aminoisobutyrate are not constituents of proteins. Here we describe the contrast- 
ing effects of dietary protein levels on the expression and activity of $\beta$-AlaAT I in the liver, kidney, and brain in rats.

\section{MATERIALS AND METHODS}

Chemicals. All reagents were of analytical grade and were purchased from Nacalai Tesque (Kyoto, Japan) unless otherwise stated. $\beta-\left[2-{ }^{14} \mathrm{C}\right]$ Alanine and $[\alpha-$ $\left.{ }^{32} \mathrm{P}\right] \mathrm{dCTP}$ were purchased from Amersham Pharmacia Iotech (Buckinghamshire, UK). Materials for the animals' diet were obtained from Oriental Yeast (Tokyo, Japan).

Animals. Male albino rats (Crj: Wistar strain, weighing 90 to $100 \mathrm{~g}$ ) were purchased from Charles River Japan (Atsugi, Japan) and housed in individual screenbottomed cages in a room maintained at $23 \pm 1^{\circ} \mathrm{C}$ with $50 \%$ humidity under controlled lighting conditions (lights on from 7 a.m. to 7 p.m. and lights off from 7 p.m. to 7 a.m.). The rats were fed a commercial stock diet (Oriental MF, Oriental Yeast) and given tap water ad libitum for $1 \mathrm{wk}$ before the experiment to allow acclimatization to the new environment. Acclimatized rats showing progressive weight gain were selected and separated into groups of six animals. The animals were sacrificed between 9 a.m. and 11 a.m. under anesthesia with diethyl ether. The liver, kidneys, and brain were quickly removed, chilled with liquid nitrogen, and stored at $-80^{\circ} \mathrm{C}$ until use. All procedures were performed under Kobe-Gakuin University Guidelines for the Care and Use of Laboratory Animals.

The following three experiments were performed. Experiment 1: Eighteen rats were assigned to three groups after the stabilization period. The three groups were given the protein-free, $5 \%$ protein, or $20 \%$ protein diet ad libitum for $14 \mathrm{~d}$. Experiment 2: Twenty-four rats were assigned to four groups. These groups were given the $5 \%$ protein, $20 \%$ protein, $40 \%$ protein, and $60 \%$ protein diets ad libitum for $28 \mathrm{~d}$. Experiment 3: Twelve rats were assigned to two groups. One group was given the $20 \%$ protein diet and the other one was given the $\beta$ alanine diet ad libitum for $14 \mathrm{~d}$.

Diets. The compositions of the low- and high-protein diets are shown in Table 1 . The $\beta$-alanine diet contained $5 \% \beta$-alanine and $53 \%$ dextrin, and the contents of other ingredients were the same as the $20 \%$ protein diet in Table 1. The diet was in powder form and contained in a glass jar $9 \mathrm{~cm}$ in diameter covered with a stainless steel lid containing nine holes $1.2 \mathrm{~cm}$ in diameter. All rats were given the experimental diet and deionized water ad libitum until they were sacrificed.

Enzyme assays. Each organ was homogenized in 10 volumes of $10 \mathrm{~mm}$ potassium phosphate, $\mathrm{pH} 7.5$, containing $1 \mathrm{~mm}$ EDTA, $2 \mathrm{~mm}$ 2-mercaptoethanol, and $40 \mu \mathrm{M}$ pyridoxal $5^{\prime}$-phosphate. The homogenate was briefly centrifuged at 3,000 rpm for $10 \mathrm{~min}$. The supernatant was used as the sample for enzyme assays.

The activities of $\beta$-AlaAT I and $\beta$-AlaAT II were determined by the amount of malonate semialdehyde produced from $\beta$-alanine using 2-oxoglutarate and pyruvate, respectively, according to the methods described
Table 1. Compositions of the diets $(\mathrm{g} / \mathrm{kg})$.

\begin{tabular}{lrrrrr}
\hline \multirow{2}{*}{ Ingredients } & \multicolumn{5}{c}{ Protein concentration (\%) } \\
\cline { 2 - 6 } & 0 & 5 & 20 & 40 & 60 \\
\hline Egg albumin & 0 & 50 & 200 & 400 & 600 \\
Dextrin & 780 & 730 & 580 & 380 & 180 \\
Corn oil & 60 & 60 & 60 & 60 & 60 \\
Vitamin mixture* & 20 & 20 & 20 & 20 & 20 \\
Salt mixture** & 60 & 60 & 60 & 60 & 60 \\
Cellulose powder & 80 & 80 & 80 & 80 & 80 \\
\hline
\end{tabular}

* The vitamins $(\mathrm{mg} / \mathrm{kg}$ of diet) were retinyl acetate (2.01), cholecalciferol (0.03), $\alpha$-tocopheryl acetate (58.5), menadione (60.8), thiamin hydrochloride (14.0), riboflavin (46.8), pyridoxine hydrochloride (9.4), cyanocobalamin (0.006), ascorbic acid (351), D-biotin (0.23), folic acid (2.34), calcium pantothenate (58.5), paminobenzoic acid (58.5), niacin (70.2), and choline chloride $(2,340)$.

** The minerals $\left(\mathrm{g} / \mathrm{kg}\right.$ of diet) were $\mathrm{CaHPO}_{4} \cdot 2 \mathrm{H}_{2} \mathrm{O}$ (4.557), $\mathrm{KH}_{2} \mathrm{PO}_{4}$ (8.050), $\mathrm{NaH}_{2} \mathrm{PO}_{4} \quad(2.927), \mathrm{NaCl}$ (1.459), Ca-lactate (10.983), Fe-citrate (0.995), $\mathrm{MgSO}_{4}$ (2.244), $\mathrm{ZnCO}_{3}(0.034), \mathrm{MnSO}_{4} \cdot 4-6 \mathrm{H}_{2} \mathrm{O}(0.038), \mathrm{CuSO}_{4}$. $5 \mathrm{H}_{2} \mathrm{O}(0.009)$, and $\mathrm{KI}(0.003)$.

previously $(6,7)$. The standard reaction mixture contained $50 \mathrm{~mm}$ sodium borate ( $\mathrm{pH} \mathrm{8.8),} 5 \mathrm{~mm} 2$-mercaptoethanol, $0.5 \mathrm{~mm}$ pyridoxal 5'-phosphate, $1 \mathrm{~mm} \beta$-[2${ }^{14} \mathrm{C}$ ]alanine (spec. act. $37 \mathrm{GBq} / \mathrm{mol}$ ), and $1 \mathrm{~mm} 2$-oxoglutarate or $1 \mathrm{~mm}$ pyruvate in a final volume of $1.0 \mathrm{~mL}$. Incubation was carried out in a shaking water bath for $30 \mathrm{~min}$ with 30 strokes/min. The reaction was terminated by the addition of $0.5 \mathrm{~mL} 2 \mathrm{M} \mathrm{HCl}$, and the tube was immediately transferred to an ice bath. After the addition of $0.02 \mathrm{~mL} 1 \mathrm{~m} \beta$-alanine and $0.2 \% 2$,4-dinitorophenylhydrazine (in $2 \mathrm{M} \mathrm{HCl}$ ), the mixture was allowed to stand at $37^{\circ} \mathrm{C}$ for $15 \mathrm{~min}$, and the dinitrophenylhydrazone formed was extracted by shaking with $5.0 \mathrm{~mL}$ toluene. After brief centrifugation, the radioactivity in 2-mL aliquots of the extract was measured in a 10-mL toluene scintillater $(5 \mathrm{~g}$ 2,5-diphenyloxazole and $0.3 \mathrm{~g}$ 1,4-bis[2-(5-phenyloxazolyl]benzen in $1 \mathrm{~L}$ toluene), with a Packard Tri-Carb liquid scintillation spectrometer (460 CD type, Meriden, CT, USA).

Tyrosine aminotransferase activity was determined by the method of Granner and Tomkins (17). Ornithine aminotransferase activity was determined by measuring the formation of L-alanine with alanine dehydrogenase at $340 \mathrm{~nm}$. Protein concentration was measured by the Lowry method (18) with bovine serum albumin as the standard.

Northern blotting. The probes of $\beta$-AlaAT I and $\beta$ AlaAT II for northern hybridization were prepared as described previously (15).

Total RNA from the rat organs was extracted by the acid guanidinium isothiocyanate/phenol/chloroform method. Poly(A)-rich RNA was prepared from the total RNA with Oligotex ${ }^{\mathrm{TM}}$-dT 30 (Takara Shuzo, Kusatsu, Japan). Aliquots of $3 \mu \mathrm{g}$ of poly(A) RNA were denatured by heating at $65^{\circ} \mathrm{C}$ for $5 \mathrm{~min}$, separated by elec- 
trophoresis in 1\% agarose gels containing 17.5\% formaldehyde and transferred onto nylon membranes. The membranes were hybridized with $\beta$-AlaAT I, $\beta$ AlaAT II, and actin probes, which were labeled with ${ }^{32} \mathrm{P}$ by means of a random primer labeling kit (Takara Shuzo), at $42^{\circ} \mathrm{C}$ overnight in $5 \times \operatorname{SSPE}(0.75 \mathrm{M}$ sodium chloride, $0.05 \mathrm{M}$ sodium phosphate, $\mathrm{pH} 7.5$, and $5 \mathrm{~mm}$ EDTA), $50 \%$ formamide, $5 \times$ Denhardts' reagent, $0.5 \%$ SDS, and $200 \mu \mathrm{g} / \mathrm{mL}$ sonicated salmon sperm DNA. The membranes were washed four times at $42^{\circ} \mathrm{C}$ for 15 min with $2 \times$ SSPE and $0.1 \%$ SDS, followed by further washing with $1 \times$ SSPE and $0.1 \%$ SDS for 20 min.

Statistical analysis. Changes associated with lowand high-protein diets are expressed as means \pm SE. A one-way analysis of variance (ANOVA) was used to compare the groups. When a significant difference $(p<0.05)$ was found between groups, the statistical significance of the differences between values was assessed by using Duncan's multiple comparison test, with $p<0.05$ considered significant. In the $\beta$-alanine diet, the statistical significance of differences between values was assessed by a Student's $t$-test.

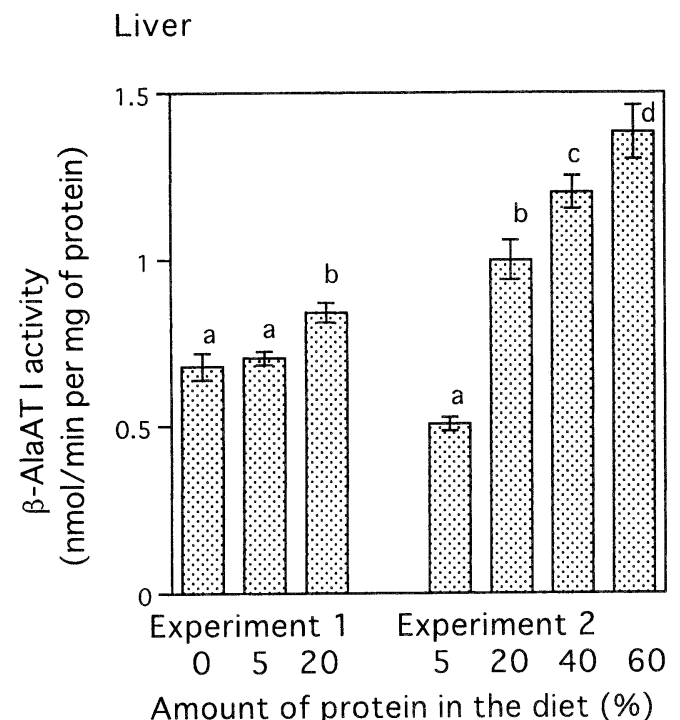

Brain

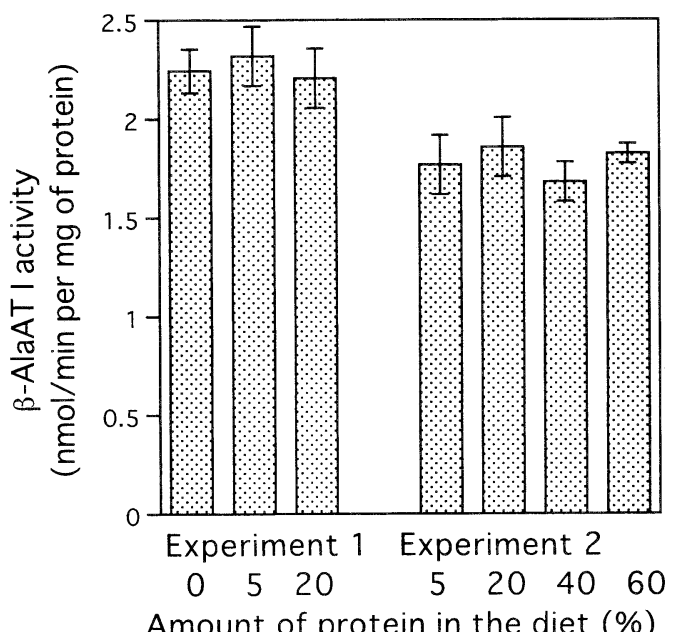

Amount of protein in the diet (\%)

\section{RESULTS}

Effects of amount of dietary protein on $\beta$-AlaAT I and $\beta$ AlaAT II activities

In experiment 1 the weight gains (mean \pm SE) of rats fed protein-free, $5 \%$ casein, and $20 \%$ casein diets for $2 \mathrm{wk}$ were $-36.8 \pm 0.8 \mathrm{~g},-2.7 \pm 0.8 \mathrm{~g}$, and $92.5 \pm$ $2.7 \mathrm{~g}$, respectively; liver wet weights were $3.57 \pm 0.13 \mathrm{~g}$, $4.12 \pm 0.19 \mathrm{~g}$, and $10.59 \pm 0.79 \mathrm{~g}$, respectively; and kidney wet weights were $0.58 \pm 0.07 \mathrm{~g}, 0.95 \pm 0.04 \mathrm{~g}$, and $1.61 \pm 0.07 \mathrm{~g}$, respectively. In experiment 2 , the weight gains of rats fed $5 \%, 20 \%, 40 \%$, and $60 \%$ casein diets for $4 \mathrm{wk}$ were $2.0 \pm 4.2 \mathrm{~g}, 168.8 \pm 4.2 \mathrm{~g}, 191.0 \pm 8.3 \mathrm{~g}$, and $173.8 \pm 4.6 \mathrm{~g}$, respectively; liver wet weights were $4.58 \pm 0.34 \mathrm{~g}, \quad 11.72 \pm 0.45 \mathrm{~g}, 12.92 \pm 0.77 \mathrm{~g}$, and $12.80 \pm 0.52 \mathrm{~g}$, respectively; and kidney wet weights were $0.88 \pm 0.04 \mathrm{~g}, 2.12 \pm 0.06 \mathrm{~g}, 2.57 \pm 0.08 \mathrm{~g}$, and $2.65 \pm 0.08 \mathrm{~g}$, respectively.

Figures 1 and 2 show the activities of $\beta$-AlaAT I and $\beta$-AlaAT II, and the effects of dietary protein level on the activities of both enzymes. Enzyme activity was expressed as $\mathrm{nmol} / \mathrm{min}$ per $\mathrm{g}$ of protein, and $\beta$-AlaAT I and $\beta$-AlaAT II activities in rat liver were shown to increase with the level of protein in the diet (Figs. 1A and

\section{Kidney}

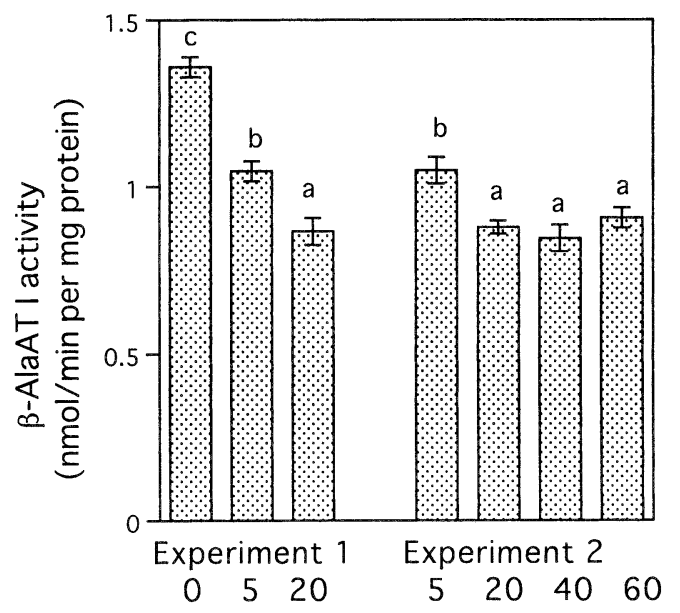

Amount of protein in the diet (\%)
Fig. 1. Effects of dietary protein levels on rat $\beta$-AlaAT I in the liver, kidney and brain. The different diets were given to the rats for $2 \mathrm{wk}$ and $4 \mathrm{wk}$ in Experiments 1 and 2 , respectively. The activity of $\beta$-AlaAT I was determined as described in MATERIALS AND METHODS. Each value is the mean \pm SE for six rats. Values not sharing a common superscript letter are significantly different $(p<0.05)$. 

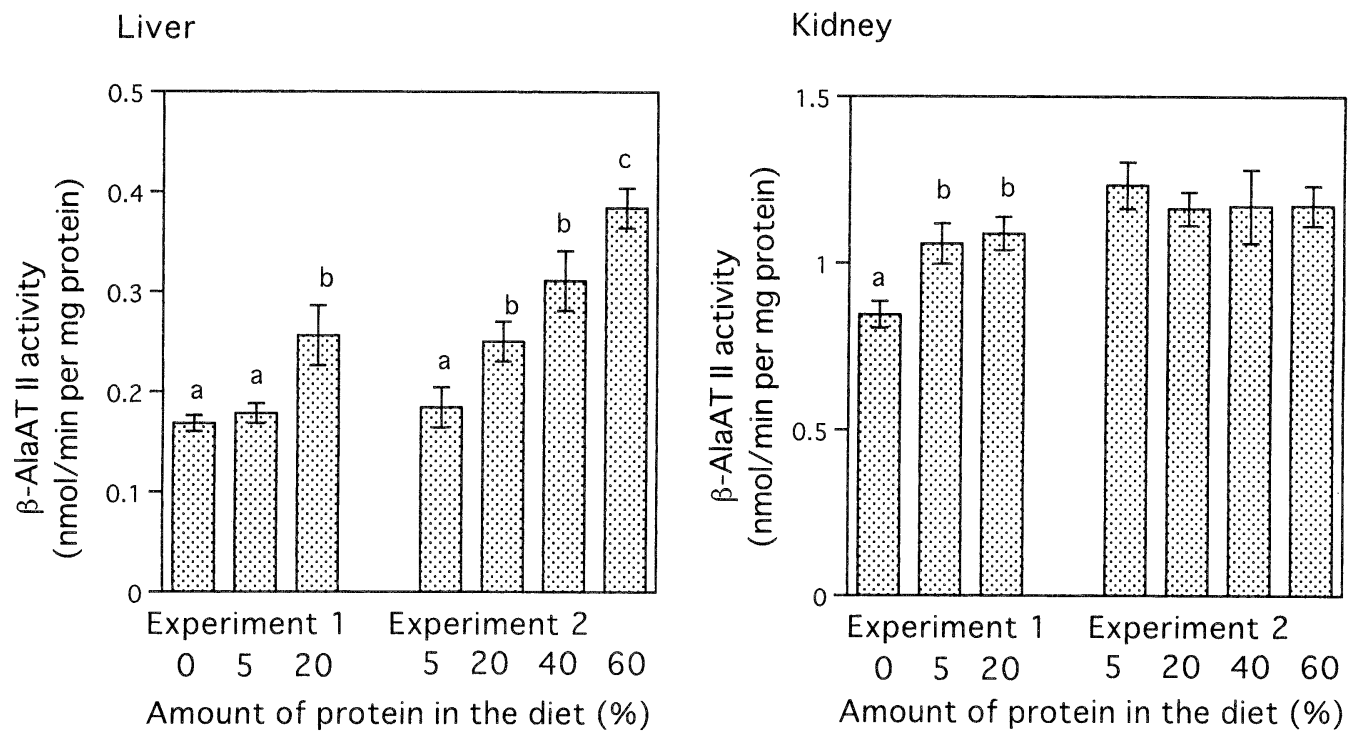

Fig. 2. Effects of dietary protein levels on rat $\beta$-AlaAT II in the liver and kidney. The different diets were given to the rats for $2 \mathrm{wk}$ and $4 \mathrm{wk}$ in Experiments 1 and 2, respectively. The activity of $\beta$-AlaAT II was determined as described in MATERIALS AND METHODS. Each value is the mean \pm SE for six rats. Values not sharing a common superscript letter are significantly different $(p<0.05)$.

Table 2. Effects of dietary protein level on rat kidney tyrosine aminotransferase and ornithine aminotransferase activities.

Tyrosine aminotransferase (nmol/min per mg protein)
Ornithine aminotransferase

(nmol/min per mg protein)
Experiment 1
$0 \%$ Protein
$5 \%$ Protein
$4.48 \pm 0.13$
$8.37 \pm 0.16$
20\% Protein
$4.13 \pm 0.14$
$8.28 \pm 0.14$
Experiment 2
$4.35 \pm 0.15$
$8.79 \pm 0.71$
$5 \%$ Protein
$3.72 \pm 0.19^{\mathrm{a}}$
$20 \%$ Protein
$3.88 \pm 0.23^{\mathrm{ab}}$
$7.62 \pm 0.53$
$40 \%$ Protein
$4.31 \pm 0.10^{\mathrm{bc}}$
$7.39 \pm 0.34$
$60 \%$ Protein
$4.50 \pm 0.08^{\mathrm{c}}$
$7.20 \pm 0.40$
$6.80 \pm 0.61$

The different diets were given to the rats for $2 \mathrm{wk}$ and $4 \mathrm{wk}$ in Experiments 1 and 2, respectively. The activities of tyrosine amimotransferase and ornithine aminotransferase were determined as described in MATERIALS AND METHODS. Each value is the mean \pm SE for six rats. Values not sharing a common superscript letter are significantly different $(p<0.05)$.

2A). In contrast, $\beta$-AlaAT I activity in the kidneys of rats fed a protein-free or a $5 \%$ protein diet was significantly increased (Fig. 1B). The activity of $\beta$-AlaAT II in the kidneys of rats fed a protein-free diet was decreased, but was not influenced by a high-protein diet (Fig. 2B). Protein in the diet from 0 to $60 \%$ did not change the activity of $\beta$-AlaAT I in the brain (Fig. 1C), in which no $\beta$ AlaAT II activity was detected.

$\beta$-AlaAT I and $\beta$-AlaAT II activities were expressed as $\mathrm{nmol} / \mathrm{min}$ per $\mathrm{g}$ of tissue, and the effects of the amount of dietary protein on both enzymes were similar to the above results (not shown).

The specific activity of tyrosine aminotransferase in the kidneys increased with the protein level in the diet (Table 2, Experiment 2). The specific activity of ornithine aminotransferase in the kidneys was not influenced by the level of protein in the diet (Table 2).
Effects of dietary protein on $\beta$-AlaAT I and $\beta$-AlaAT II $m R N A$ s in the liver and kidney

The levels of expression of $\beta$-AlaAT I and $\beta$-AlaAT II mRNAs and the effects of dietary protein on their expression are shown in Fig. 3 and Table 3. We detected two transcripts of approximately 2.4 and $6.4 \mathrm{~kb}$ from $\beta$ AlaAT I (Fig. 3). The smaller species was the main transcript of $\beta$-AlaAT I cDNA and contained the full-length coding region. Because a Southern hybridization analysis indicated that the $\beta$-AlaAT I gene was present in only a single copy per haploid (13), the other mRNA species may have been a nonprocessed transcript.

$\beta$-AlaAT I and $\beta$-AlaAT II gene expression in the liver were stimulated by increases in the dietary protein level. In contrast, the $\beta$-AlaAT I mRNA level in the kidney was increased by a protein-free diet. The ratios of the expression of $\beta$-AlaAT I mRNA between the protein- 


\section{Experiment 1}

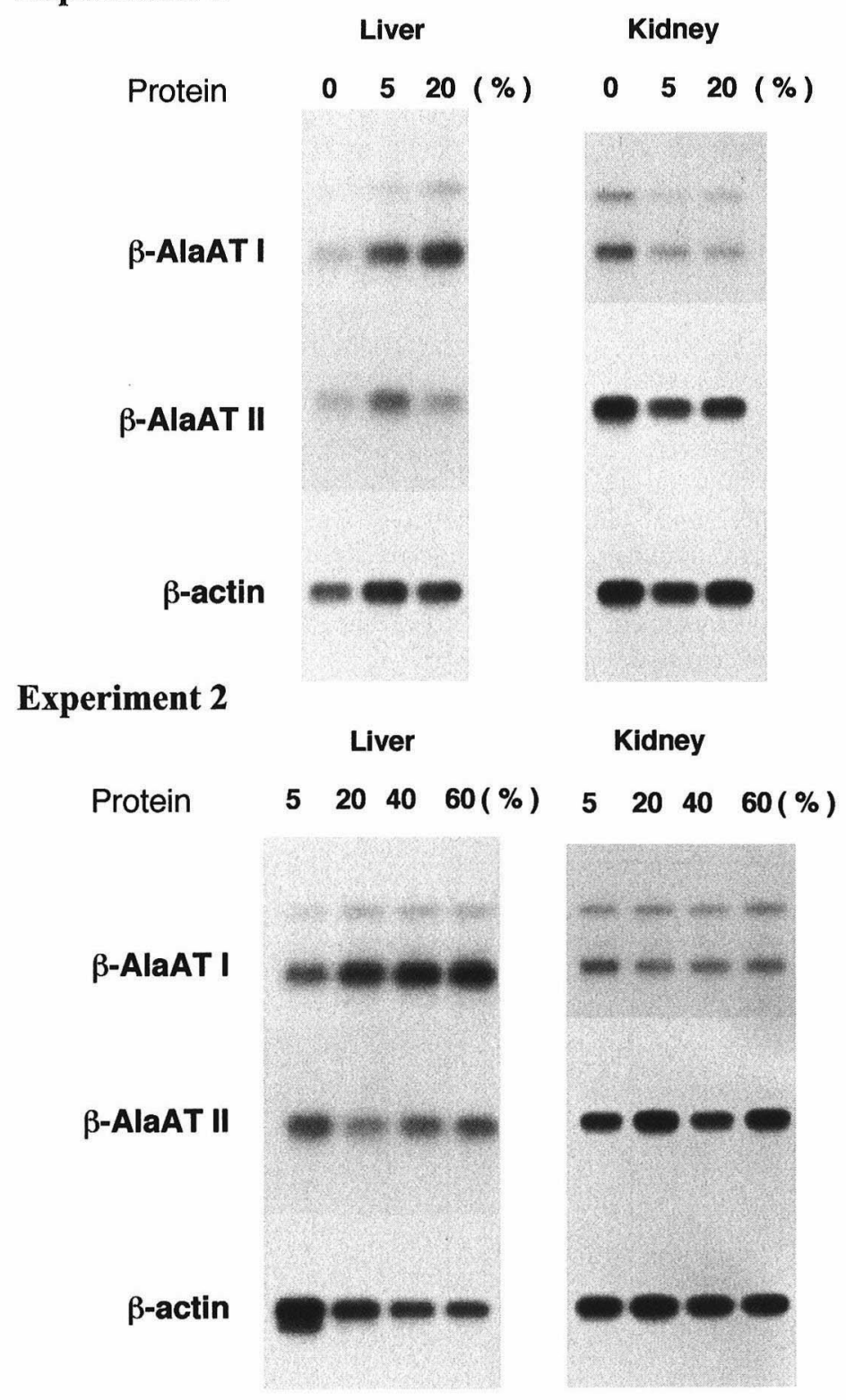

Fig. 3. Northern blotting analysis of liver and kidney poly(A) RNA from rats fed diets containing different levels of protein. The different diets were given to the rats for $2 \mathrm{wk}$ and $4 \mathrm{wk}$ in Experiments 1 and 2, respectively. The protein levels in the diets are indicated as percentages above each lane.

free diet and $20 \%$ casein groups in the liver and kidney were about 0.24 and 2.5 , respectively. Conversely, the $\beta$-AlaAT I mRNA level in the kidney was increased by protein-free and 5\% protein diets in Experiment 1. $\beta$ AlaAT I mRNA level in the kidney was not affected by a 5\% protein diet in Experiment 2. This discrepancy may have been due to differences in the feeding period between Experiments 1 and 2 . The level of $\beta$-AlaAT I mRNA in the kidney was not affected by high-protein diets. The kidney $\beta$-AlaAT II gene expression was not affected by the dietary protein level.

Effects of dietary $\beta$-alanine on $\beta$-AlaAT I and $\beta$-AlaAT II activities and their mRNAs in the kidney

In Experiment 3, the weight gains (mean \pm SE) of rats fed $\beta$-alanine and $20 \%$ casein control diets for $2 \mathrm{wk}$ were $77.7 \pm 1.9 \mathrm{~g}$ and $82.5 \pm 4.1 \mathrm{~g}$, respectively. There were no significat differences between the groups.
The activities of $\beta$-AlaAT I and $\beta$-AlaAT II in the kidney of rats fed a $\beta$-alanine-diet were significantly increased to 1.2-fold and 1.6-fold, respectively, in accordance with their mRNAs (Fig. 4). However, $\beta$-alanine in the diet did not influence the activities of $\beta$-AlaAT I or $\beta$-AlaAT II in the liver. The activities of $\beta$-AlaAT I and $\beta$-AlaAT II in the liver of rats fed the control diet were $0.966 \pm 0.031$ and $0.204 \pm 0.009 \mathrm{nmol} / \mathrm{min}$ per $\mathrm{mg}$ protein, respectively. These enzyme activities in the liver of rats fed the $\beta$-alanine-diet were $0.993 \pm 0.052$ and $0.219 \pm 0.019 \mathrm{nmol} / \mathrm{min}$ per $\mathrm{mg}$ protein, respectively. Dietary $\beta$-alanine also did not change the activity of $\beta$ AlaAT I in the brain ( $\beta$-alanine diet group, $1.324 \pm$ $0.086 \mathrm{nmol} / \mathrm{min}$ per $\mathrm{mg}$ protein; control group, $1.293 \pm$ $0.087 \mathrm{nmol} / \mathrm{min}$ per $\mathrm{mg}$ protein). 
Table 3. Effects of dietary protein on $\beta$-AlaAT I and $\beta$-AlaAT II mRNA levels in the rat liver and kidney.

\begin{tabular}{|c|c|c|c|c|}
\hline & \multicolumn{2}{|c|}{ Liver } & \multicolumn{2}{|c|}{ Kidney } \\
\hline & $\beta$-AlaAT I & $\beta$-AlaAT II & $\beta$-AlaAT I & $\beta$-AlaAT II \\
\hline \multicolumn{5}{|l|}{ Experiment 1} \\
\hline $0 \%$ Protein & $0.37 \pm 0.05^{a}$ & $0.17 \pm 0.02^{\mathrm{a}}$ & $0.59 \pm 0.03^{c}$ & $0.93 \pm 0.05$ \\
\hline $5 \%$ Protein & $1.11 \pm 0.08^{b}$ & $0.41 \pm 0.05^{b}$ & $0.41 \pm 0.03^{b}$ & $0.87 \pm 0.04$ \\
\hline $20 \%$ Protein & $1.54 \pm 0.08^{c}$ & $0.44 \pm 0.04^{\mathrm{b}}$ & $0.24 \pm 0.02^{\mathrm{a}}$ & $0.83 \pm 0.06$ \\
\hline \multicolumn{5}{|l|}{ Experiment 2} \\
\hline $5 \%$ Protein & $1.15 \pm 0.07^{\mathrm{a}}$ & $0.71 \pm 0.04^{\mathrm{a}}$ & $0.84 \pm 0.06$ & $0.77 \pm 0.05$ \\
\hline $20 \%$ Protein & $1.64 \pm 0.05^{b}$ & $0.82 \pm 0.06^{\mathrm{a}}$ & $0.75 \pm 0.03$ & $0.82 \pm 0.04$ \\
\hline $40 \%$ Protein & $1.90 \pm 0.12^{\mathrm{c}}$ & $1.12 \pm 0.10^{b}$ & $0.77 \pm 0.05$ & $0.85 \pm 0.06$ \\
\hline $60 \%$ Protein & $2.09 \pm 0.08^{\mathrm{d}}$ & $1.18 \pm 0.07^{b}$ & $0.76 \pm 0.03$ & $0.90 \pm 0.08$ \\
\hline
\end{tabular}

Poly(A)-rich RNAs from rat liver and kidney were prepared, and northern blotting was performed as described in MATERIALS AND METHODS. The quantity of mRNA was estimated with GeneQuant (Pharmacia, Uppsala, Sweden), and $3 \mu \mathrm{g}$ aliquots were analyzed. The values are expressed as a relative intensity of the signals calculated with a Bio-Imaging Analyzer FLA-2000 (Fuji Photo Film, Tokyo, Japan) and are means \pm SE from six rats. Values not sharing a common superscript letter are significantly different $(p<0.05)$.

\section{$\beta$-AlaAT I}

(A)

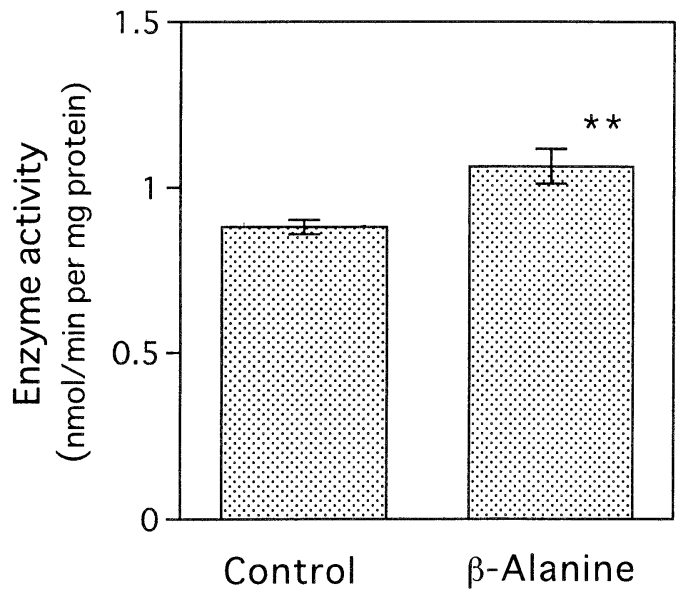

$\beta$-AlaAT II

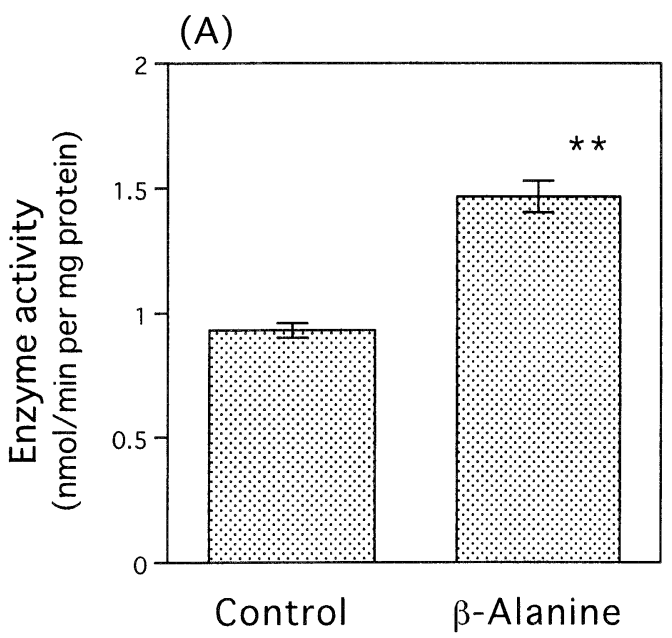

(B)

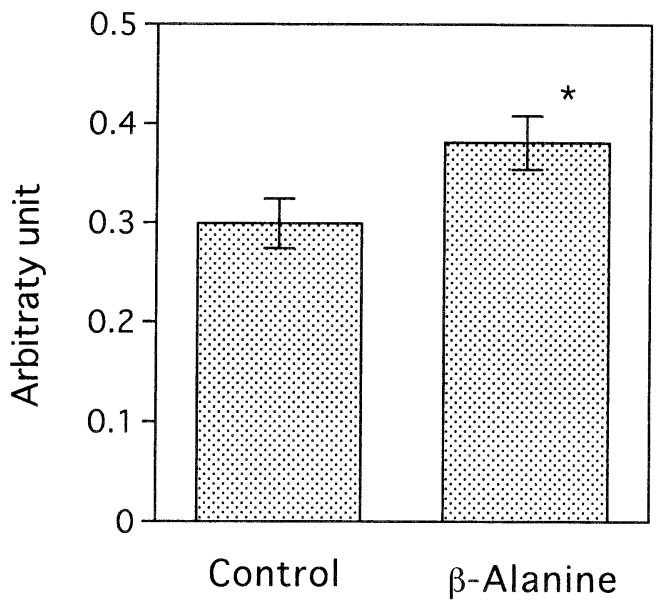

(B)

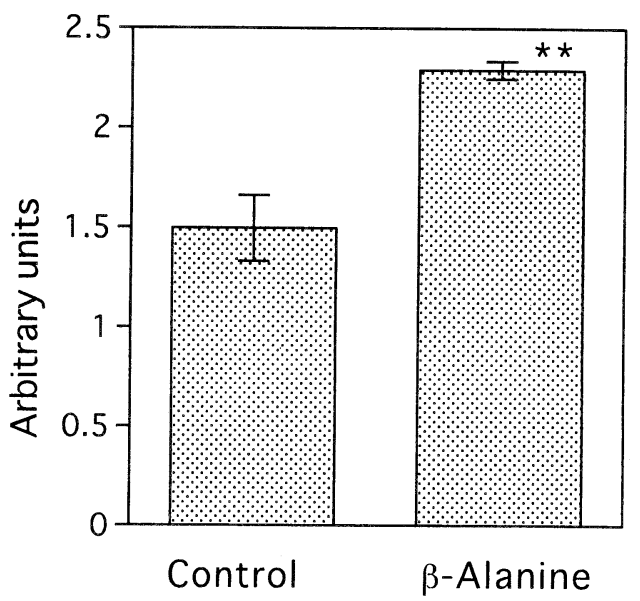

Fig. 4. $\quad$ Effects of dietary $\beta$-alanine on rat kidney $\beta$-AlaAT I and $\beta$-AlaAT II. (A) Enzyme activity. (B) mRNA. The control diet and the $\beta$-alanine-diet were given to the rats for $2 \mathrm{wk}$. The enzyme activities and the mRNA levels were determined as described in MATERIALS AND METHODS. Each value is the mean \pm SE for six rats. ${ }^{*} p<0.05$ and ${ }^{* *} p<0.01$ compared with control. 


\section{DISCUSSION}

Aspartate aminotransferase, alanine aminotransferase, and tyrosine aminotransferase levels in the liver are increased by high levels of dietary protein $(19,20)$. Previously (16), the activities of $\beta$-AlaAT I and $\beta$-AlaAT II in the rat liver were shown to be dependent on the amount of protein in the diet. Here we found changes in the expression of $\beta$-AlaAT I and $\beta$-AlaAT II mRNAs regulated by dietary protein level preceding those in both enzyme activities. $\beta$-AlaAT I activity in the rat liver was significantly increased by glucocorticoid administration (21). The mean plasma corticosterone concentration is decreased in rats fed a low-protein diet relative to those fed a high-protein $\operatorname{diet}(22)$. Although $\beta$-alanine and $\beta$ aminoisobutyrate are not contained in proteins, both $\beta$ AlaAT I and $\beta$-AlaAT II gene expression may be influenced by the level of dietary protein. Further studies are required to resolve this issue.

In contrast, the activities of $\beta$-AlaAT I and $\beta$-AlaAT II in the kidneys of rats were not influenced by the amount of protein in the diet. The kidneys of rats fed protein-free and low-protein diets showed stimulated $\beta$ AlaAT I gene expression, followed by increases in $\beta$ AlaAT I activity. These results suggest that the regulatory effects of dietary protein on $\beta$-AlaAT I are different between the liver and kidney and from other aminotransferases.

Carnosine content in rat muscle is about $8 \mathrm{~mm}$ (23), and it is mainly hydrolyzed in the kidney $(24,25)$. The sum of the concentrations of the 20 free amino acids that are constituents of protein in rat muscle has been calculated to be about $5 \mathrm{~mm}$ (23). The level of carnosine is decreased to 3.5 and $2 \mathrm{~mm}$ by feeding protein-free and $5 \%$ protein diets for $2 \mathrm{wk}$, respectively (23). On the other hand, the sum of the concentrations of the 20 free amino acids in the muscle of rats fed a protein-free diet is about $3.4 \mathrm{~mm}$. $\beta$-Alanine formed from carnosine in muscle under conditions of dietary protein deficiency may be available for use as a nitrogen source via glutamate formed from $\beta$-AlaAT I reaction. Feeding with a low-protein diet significantly increases the specific activity of glutamine synthase in the kidney compared with that obtained from a high-protein diet (26).

Here we found that the kidneys of rats fed the $\beta$-alanine-diet showed increases in $\beta$-AlaAT I and $\beta$-AlaAT II activities in relation to changes in their mRNA levels. $\beta$ Alanine may have a greater effect on the gene expression of $\beta$-AlaAT I than on $\beta$-AlaAT II because the $\beta$ AlaAT II mRNA was not influenced by the level of protein in the diet.

$\beta$-AlaAT I activity in the rats is the most active in the brain, followed by the liver and kidney (Fig. 1). $\beta$-AlaAT I functions mainly in the catabolism of 4-aminobutyrate (GABA) in the brain because the concentrations of GABA and $\beta$-alanine are $4 \mathrm{~mm}$ and $0.001-0.04 \mathrm{~mm}$ in the brain $(27,28)$. The uracil catabolizing enzymes dihydrouracil dehydrogenase, dihydropyrimidinase, and $\beta$-ureidopropionase are mainly distributed in the liver and kidney (29-31). GABA is a major inhibitory trans- mitter in many invertebrate systems and in the vertebrate central nervous system (32-34). Therefore $\beta$ AlaAT I (GABA aminotransferase) activity in the brain may not be influenced by the level of protein in the diet or $\beta$-alanine-diet and may be regulated to maintain a constant normal level.

\section{REFERENCES}

1) Fink K, Henderson RB, Fink RM. 1952. $\beta$ Aminoisobutyric acid in rat urine following administration of pyrimidines. J Biol Chem 197: 441-452.

2) Fink RM, Fink K, Henderson RB. 1953. $\beta$-Amino acid formation by tissue slices incubated with pyrimidines. $J$ Biol Chem 201: 349-355.

3) Canellakis ES. 1956. Pyrimidine metabolism. I. Ezymatic pathways of uracil and thymine degradation. J Biol Chem 221: 315-322.

4) Fritzson P. 1957. The catabolism of ${ }^{14} \mathrm{C}$-labeled uracil, dihydrouracil, and $\beta$-ueidopropionic acid in rat liver slices. J Biol Chem 226: 223-228.

5) Tamaki N, Morioka S, Ikeda T, Harada M. 1980. Biosynthesis and degradation of carnosine and turnover rate of its constituent amino acids in rats. $J$ Nutr Sci Vitaminol 26: 127-139.

6) Tamaki N, Aoyama H, Kubo K, Ikeda T, Hama T. 1982. Purification and properties of $\beta$-alanine aminotransferase from rabbit liver. $J$ Biochem (Tokyo) 92: 1009-1017.

7) Tamaki N, Kaneko M, Mizota C, Kikugawa M, Fujimoto S. 1990. Purification, and characterization and inhibition of D-3-aminoisobutyrate aminotransferase from the rat liver. Eur J Biochem 189: 39-45.

8) Goodwin GW, Rougraff PM, Davis FJ, Harris RA. 1989. Purification and characterization of methylmalonatesemialdehyde dehydrogenase from rat liver: Idintity to malonate-semialdehyde dehydrogenase. J Biol Chem 264: 14965-14971.

9) Tamaki N, Fujimoto S, Mizota C, Kikugawa M. 1987. Identity of $\beta$-alanine-oxo-glutarate aminotransferase and $\mathrm{L}-\beta$-aminoisobutyrate aminotransferase in rat liver. Biochim Biophys Acta 925: 238-240.

10) Kontani Y, Kaneko M, Kikugawa M, Fujimoto S, Tamaki N. 1993. Identity of D-3-aminoisobutyrate-pyruvate aminotransferase with alanine-glyoxylate aminotransferase 2. Biochim Biophys Acta 1156: 161-166.

11) Kontani $Y$, Sakata SF, Matsuda K, Ohyama T, Sano K, Tamaki N. 1999. The mature size of rat 4-aminobutyrate aminotransferase is different in liver and brain. Eur J Biochem 264: 218-222.

12) Tamaki N, Sakata SF, Matsuda K. 2000. Purification, properties, and sequencing of aminoisobutyrate aminotransferases from rat liver. Methods Enzymol 324: 376-389.

13) Medina-Kauwe LK, Tillakaratue NJK, Wu J-Y, Tobin AJ. 1994. A rat brain cDNA encodes enzymatically active GABA-transaminase and provides a molecular probe for GABA-catabolizing cells. J Neurochem 62: $1267-$ 1275 .

14) Osei YD, Churchich JE. 1995. Screening and sequence determination of a cDNA encoding the human brain 4aminobutyrate aminotransferase. Gene 155: 185-187.

15) Kontani Y, Kawasaki S, Kaneko M, Matsuda K, Sakata SF, Tamaki N. 1998. Inhibitory effect of ethanol administration on $\beta$-alanine-2-oxoglutarate aminotransferase (GABA aminotransferase) in disulfiram-pretreated rats. 
J Nutr Sci Vitaminol 44: 165-176.

16) Kaneko M, Fujimoto S, Kikugawa M, Kontani Y, Tamaki N. 1991. Effect of dietary protein on pyrimidine-metabolizing enzymes in rats. J Nutr Sci Vitaminol 37: 517528.

17) Granner DK, Tomkins BM. 1970. Tyrosine aminotransferase (rat liver). Methods Enzymol 17A: 633-637.

18) Lowry OH, Rosebroughy NJ, Farr AL, Randall RJ. 1951. Protein measurement with Folin phenol reagent. J Biol Chem 193: 265-275.

19) Szepesi B, Freedland RA. 1967. Alterations in the activities of several rat liver enzymes at various times after initiation of a high protein regimen. J Nutr 93: 301306.

20) Krebs HA. 1971. Some aspects of the reglulation of fuel supply in omnivorous animals. Adv Enzyme Regul 10: 379-420.

21) Mizota C, Fujimoto S, Kikugawa M, Kimura Y, Tamaki N. 1988. Effect of pyridoxine deficiency and prednisolone on $\beta$-alanine-oxoglutarate aminotransferase and D-3-aminoisobutyrate aminotransferase in rat liver and kidney. J Nutr Sci Vitaminol 34: 223-236.

22) Knepper MA, Danielson RA, Saidel GM, Johnston KH. 1975. Effects of dietary protein restriction and glucocorticoid administration on urea excretion in rats. Kidney Int 8: 303-315.

23) Tamaki N, Hama T. 1976. Effect of thyroid hormon and dietary protein level on the contents of anserine and carnosine in gastrocnemius muscle of rats. Nippon Eiyo Shokuryo Gakkaishi (J Jpn Soc Nutr Food Sci) 29: 317 324 (in Japanese).

24) Lenny JF. 1976. Specificity and distribution of mammalian carnosinase. Biochim Biophys Acta 429: 214 219.
25) Tamaki N, Ikeda T, Fujimoto S, Mizutani N. 1985. Carnosine as a histidine source: Transport and hydrolysis of exogeneous carnosine by rat intestine. J Nutr Sci Vitaminol 31: 607-618.

26) Matsuzawa T, Kobayashi T, Tashiro K, Kasahara M. 1994. Changes in ornithine metabolic enzymes induced by dietary protein in small intestine and liver: Intestine-liver relationship in ornithine supply to liver. $J$ Biochem (Tokyo) 116: 721-727.

27) Yoshino Y, De Feudis FV, Elliott KAC. 1970. Omegaamino acids in rat brain. Can J Biochem 48: 147-148.

28) Perry TL, Berry K, Hansen S, Diamond S, Mok C. 1971. Regional distribution of amino acids in human brain obtained at autopsy. J Neurochem 18: 513-519.

29) Fujimoto S, Matsuda K, Kikugawa M, Kaneko M, Tamaki N. 1991. Effect of vitamin $B_{2}$ deficiency on rat liver dihydropyrimidine dehydrogenase activity. J Nutr Sci Vitaminol 37: 89-98.

30) Kikugawa M, Kaneko M, Fujimoto-Sakata S, Maeda M, Kawasaki K, Takagi T, Tamaki N. 1994. Purification, characterization and inhibition of dihydropyrimidinase from rat liver. Eur J Biochem 219: 393-399.

31) Tamaki N, Mizutani N, Kikugawa M, Fujimoto S, Mizota C. Purification and properties of $\beta$-ureidopropionase from the rat liver. Eur J Biochem 169: 21-26.

32) Otsuka M, Iversen LL, Hall ZW. 1966. Release of gamma-aminobutyric acid from inhibitory nerves of lobster. Proc Natl Acad Sci USA 56: 1110-1115.

33) Krnjevic K, Schwarts S. 1967. The activation of $\gamma$ aminobutyric acid on cortical nerves. Exp Brain 3: 320-336.

34) Roberts E, Kuriyama K. 1968. Biochemical-physiological correlations in studies of the gamma-aminobutyric acid system. Brain Res 8 : 1-35. 